\title{
MODELING FURROW SURFACE IRRIGATION DESIGN AND PREDICTING OF INFILTRATION PARAMETERS UNDER DIFFERENT INFLOW RATES
}

\author{
GUIRGUIS; A. E. and A.M. ZAYTON
}

Agric. Eng. Res. Inst.; ARC; Dokki; Giza

(Manuscript received 21 October 2014)

\begin{abstract}
$\mathrm{M}$ athematical model is developed for furrow surface irrigation design using BASIC language to simulate all stages of the hydraulic movement of water and evaluate the performance of the accounts design of surface irrigation lines as well as to assess alternative designs for field and administrative operations. The developed model is based on the volume balance method considering the target application depth which solved by the Newton-Raphson procedure. Model performance is evaluated and verified using field data. Field experiments were conducted during 2013-2014 at a sugar crops research station- Alexandria; in clay soils. Measurement parameters included soil roughness coefficient; furrow shape parameters; (slope; width; and length) advance and recession times; cutoff time and furrow water normal depth through irrigation event are utilized to verify the accuracy of the developed model. Three different inflow rates 1.22; 1.48 and $2.37(\mathrm{I} / \mathrm{s})$ and different furrow construction shapes (Triangular; Rectangular; Trapezoid and Parabola) are used. The developed mathematical model is capable to select which furrow shape should use; and determine and predict water infiltrated depth parameters equations $(a$ and $K$ ) for any inflow rate can used. Knowledge of each of furrow cross-sectional area; the advance time to half furrow length; and advance time to the overall furrow length; volumes of water applied for each of half furrow length and overall furrow length should be predicated. By comparing the obtained model predicted date with field date; the results showe that the developed model accurately predict the hydraulic design of furrow surface irrigation and water infiltrated depth parameters as it is applicable in practice in design and contribute to the advisory work for water conservation and economic use of water.
\end{abstract}

Keywords: model; volume balance; simulation of irrigation hydraulic phases; Newton-Raphson procedure.

\section{INTRODUCTION}

Due to the increase in world population and the increased need for food and fiber; water demands have increased dramatically. This ultimately leads to concerns regarding the reliability of the natural water resources and the ability to provide stable; secure; and prosperous life. Improved irrigation management of surface irrigation systems is essential to help reduce the overall water demand since about three-fourth of the water is being used for irrigation. Also; due to our country being 
faced a shortage of water resources of the Nile River; so thinking of ways to solve this problem by improve the efficiency of furrow surface irrigation system is of great importance. This was to think about how to furrow irrigation is widely used because of its low cost and energy requirement. So; furrow irrigation method should be designed in such a manner to ensure an adequate and uniform water application over the entire field and to minimize the potential water losses.

Many researchers in this field have engaged in optimizing the design of furrow irrigation method to improve irrigation performance. However; furrow irrigation performance is affected by a range of factors including the inflow discharge; soil infiltration characteristic; field length; required application volume; cutoff time; surface roughness; and field slope (Pereira and Trout; 1999 and Eldeiry et. al.; 2005). Dimensional sensitivity analysis technique has been employed to reduce the number of independent irrigation variables within a manageable range and empirical functions have been developed for a predictive performance and design of furrow irrigation systems (Zerihun et. al.; 1997 and Navabian et. al.; 2009); but this technique is rather complex and tedious. Eldeiry et. al.;(2005) demonstrated that the furrow length and application discharge were the main factors affecting application efficiency in design of furrow irrigation in clay soil. Gillies et. al.;(2008) conducted a furrow irrigation experiment in cotton filed; which evaluated and optimized the irrigation performance. They found that the use of Irri-Prob software could optimize the field management to the maximum irrigation performance. However; the results of these studies were only adapted to the free drainage furrow irrigation. Sanchez et. al.; (2009) developed management tools and guidelines for efficient irrigation of vegetables using closedend level furrows. Results of this study indicated that adequate and efficient irrigations could be achieved through a proper selection of unit inlet flow rate and cutoff time. Ma et. al.; (2010) proposed a multi-objective optimized model for design of closed-end border irrigation system; in which a fuzzy relationship was analyzed and a fuzzy solution was presented. However; storage efficiency was not considered in their analysis. Zerihun et. al.; (2001) and Nelson and Al-Kaisi (2011) stated that the application efficiency is the primary furrow irrigation system design and management criterion. They developed a design and management algorithm that is simple enough to be part of routine design and management exercises and optimal performance with a minimum calculation effort. Schwankl et. al.; (2000) used the zero-inertia furrow irrigation model with specified space solution to investigate the effects of variability in furrow inflow rate and spatial variability in infiltration; geometry; and roughness on end-of-furrow advance; average infiltrated depth; and distribution uniformities. Their results indicated that variability of furrow physical characteristics; in decreasing order 
of their relative impact on furrow irrigation performance; were furrow inflow rate; infiltration; geometry; and roughness. For a field with highly variable soil and infiltration characteristics; spatially varying infiltration may have a greater impact than variable furrow inflow on irrigation performance. Abdel-Wahab (2005) and Ali et. al.; (2009) identified a range of methods to improve water application efficiencies including the use of appropriate furrow lengths; irrigation cutoff times and water application rates. However; simulation modeling provides an opportunity to identify more efficient practices and assess the benefits for a fraction of the time and cost of field trials. Zin El-Abedin and Ismail (1999) examined a model for the changes in the discharge at each of the accumulative infiltration equations. The model was capable of predicting the water advance curves of fronts for the different accumulative equations with the different discharge. The model gave very good prediction for the advance water. Hamed and Abdolmajid (2011); tested three commercial mathematical models in the SIRMOD package (Surface Irrigation Simulation; Evaluation and Design) including the hydrodynamic; zero inertia; and kinematic wave models using the data from several field experiments for both border and furrow irrigation systems. The results indicated that the performance of all models was satisfactory for the prediction of the advance and recession times. There was no difference in the prediction of the advance and recession times and infiltrated and runoff volumes between the hydrodynamic and zero-inertia approaches of the SIRMOD software. Also the accuracy of these models for the prediction of the advance and recession times was better for the experimental furrows in comparison with the experimental borders. Nie; et. al.;(2014) verified reliability of infiltration parameters and Manning roughness estimated with commercial SIPAR_ID software (Surface Irrigation Parameter Identification) and present an optimized method for design of closed-end furrow system. The results showed that the simulated values with the Win SRFR software (hydraulic analysis of surface irrigation systems) were in excellent agreement with the measured data.

The specific objectives of this study were to:

1- Develop BASIC software model for furrow surface irrigation design.

2- Predict the parameters of cumulative water infiltrated depth equations.

3- Verify the developed model under field conditions using field experimental data.

4- Study the effect of performance calculation (adjusting recession time) on water application efficiency (Ea) and other output parameters. 


\section{MATERIALS AND METHODS}

\section{Model development}

The design procedures outlined in the following sections are based on the volume balance method considering the target application depth which solved by the Newton- Raphson procedure. A selection of lengths; slopes; field inflow rates and cutoff times can be made that will maximize application efficiency for a particular configuration. Iterating through various configurations provide the designer with information necessary to final a global optimum. Considerations such as erosion and water supply limitations will act as constraints on the design procedures. Maximum application efficiencies; the implicit goal of design; will occur when the least-watered areas of the field receive a depth equivalent to $Z_{\text {req. }}$ Minimizing differences in intake opportunity time will minimize deep percolation. Surface runoff will be controlled or reused. The decision variables in surface irrigation are normally the field dimensions (furrow length and spacing); the flow rate; and the cutoff time.

\section{Model assumptions limitations and requirements}

The model utilizes the SI units. It can be assist the user for predicting the infiltration equation parameters and furrow geometry can be selected by the user from the following shapes: (Trapezoid; Triangle; Rectangular and Parabola).

Model Inputs: Consider collection of the following design data: field data collection and soil data measurement of hydraulic parameters (discharge; furrow geometry characteristics; advance; and recession times). The input design parameters can be summarized in Table (1).

\section{Model design processes}

The design process starts by assigning a length and flow rate to each furrow. Inputs required for design process includes: furrow discharge; flow geometry; field slope and length; to determine the rates of advance and recession. Once advance and recession are computed; the field performance levels for various combinations of inflow and cutoff times are determined. Thus; the two important design computations in surface irrigation design are: (1) computation of the advance time; and (2) computation of cutoff time; $\mathrm{T}_{\text {co. }}$.

Table 1. Required minimum input data for surface irrigation process

\begin{tabular}{|l|l|}
\hline \multicolumn{1}{|c|}{ Parameters and notes } & \multicolumn{1}{c|}{ Mathematical notations } \\
\hline Manning roughness from field data. & $\mathrm{n}$ \\
\hline Furrow geometry(Length;Width and Slope). & $\mathrm{FL} ; \mathrm{W}_{\mathrm{f}}$ and $\mathrm{S}_{\mathrm{o}}$ \\
\hline Soil erosive velocity. & $\mathrm{V}_{\max }$ \\
\hline Inflow rate and time. & $\mathrm{Q}_{\mathrm{f}}$ and $\mathrm{T}$ \\
\hline Application requirement infiltrated depth. & $\mathrm{Z}_{\mathrm{req}} \cdot$ \\
\hline Furrow hydraulic parameters. & $\mathrm{A}_{\mathrm{o}} ; \mathrm{W}_{\mathrm{p}} ; \mathrm{R}$ and $\mathrm{T}_{\mathrm{W}}$ \\
\hline
\end{tabular}


Where: $n$ :soil roughness (dimensionless); FL: furrow length $(m) ; W_{f}$ : furrow width $(\mathrm{m}) ; \mathrm{S}_{0}$ : the flow direction slope $(\mathrm{m} / \mathrm{m}) ; \mathrm{V}_{\text {max }}$ : maximum flow velocity $(\mathrm{m} / \mathrm{s}) ; \mathrm{Q}_{\mathrm{f}}$ : inflow rate $\left(\mathrm{m}^{3} / \mathrm{s}\right) ; \mathrm{T}$ : elapsed time $(\mathrm{min}) ; Z_{\text {req }}$ : requirement water infiltrated depth $(\mathrm{mm}) ; A_{0}$ : furrow cross-sectional area $\left(m^{2}\right) ; W_{p}$ : wetted perimeter $(m) ; R$ : hydraulic radius $(m)$ and $T_{W}$ : water top width $(\mathrm{m})$.

\section{The design procedures}

- Selection furrow shape type and determine furrow water normal depth $(Y)$; which matches with furrow inflow rate; $\left(Q_{f}\right)$ using iteration method.

- According to furrow water normal depth (Y mm); then the calculation of furrow hydraulic shape parameters (flow cross-section area; wetted perimeter; hydraulic radius and top width) were estimated.

- Computation of water normal velocity added to each furrow was calculated from the following equation:

$$
\mathrm{V}_{\text {in }}=\mathrm{Q}_{\mathrm{f}} / \mathrm{A}_{\mathrm{o}}
$$

The relationships (power law fitting equation) between the water normal depth and both of furrow cross-section area; top width and wetted perimeter were estimated by modeling to drive the furrow shape parameters: flow cross-section area factor parameters $\left(a_{1}\right.$ and $\left.a_{2}\right)$; top width factor parameters $\left(a_{1}\right.$ and $\left.a_{2}\right)$; wetted perimeter factor parameters $\left(b_{1}\right.$ and $\left.b_{2}\right)$. Therefore the area shape factor parameters $\sigma_{1}$ and $\sigma_{2}$ can be obtained as follows:

$$
\sigma_{1}=\frac{a_{1}}{1+a_{2}} \quad \text { and } \quad \sigma_{2}=1 \text {. }
$$

The furrow shapes and their hydraulic sectional parameters can be obtained from the following relations; (Eldeiry et. al.; 2005):

$$
\begin{aligned}
& \mathrm{P}_{2}=1.667-\left(0.667\left(\mathrm{~b}_{2} / \alpha_{2}\right)\right) \\
& \mathrm{P}_{1}=\alpha_{1}^{\left(1.667-\mathrm{P}_{2}\right)} /\left(\mathrm{b}_{1}^{0.667}\right)
\end{aligned}
$$

The cross-sectional area of the surface flow can be estimated through the Manning equation (Walker and Skogerboe; 1987) as follows:

$$
\begin{aligned}
& A_{0}=C_{1}\left(\left(Q_{0} n\right) /\left(60 S_{o}\right)\right) \\
& C_{1}=\sigma_{1}\left(b_{1}^{0.667} / \sigma_{1}^{1.667}\right) \text { and } C_{2}=\frac{3 \sigma_{2}}{5 \sigma_{2}-2 b}
\end{aligned}
$$

Where: $Q_{0}$ : furrow inflow rate; $\left(\mathrm{m}^{3} / \mathrm{min}\right)$. 
The furrow cross section must be large enough to contain the largest irrigation stream to be introduced without overtopping. Soil from the ridges tends to partially fill the furrows and; as the growing season progresses; the depth and area of the channels usually decrease. Allowances should be made for such decreases when the furrow capacity is determined. For furrows; the following geometry is assumed: furrow length; furrow width; furrow inflow rate; furrow slope and Manning roughness coefficient .The Manning roughness coefficient values have been observed as low as 0.04. Resistance to flow is usually described by the Manning equation; which relates the flow rate; the flow cross-section area; the hydraulic radius.

$$
\mathrm{Q}=\mathrm{A}_{\mathrm{o}} \mathrm{R}^{2 / 3} \mathrm{~S}_{\mathrm{o}}^{1 / 2} /\left(\mathrm{n} / \mathrm{C}_{\mathrm{u}}\right)
$$

- Computation of water advance time; as the irrigation water advanced down the furrow; arrival times were recorded at the end of each reach. Then; the advance trajectory was represented by a power function following a two point procedure as described by Elliott and Walker (1982).

$$
\mathrm{X}=\mathrm{p} \mathrm{T}^{\mathrm{a}}
$$

Where; $\mathrm{X}$ : advance distance $(\mathrm{m})$; achieved in $\mathrm{T}(\mathrm{min})$ of inflow and $(\mathrm{p}$ and $\mathrm{a})$ are fitting parameters.

- Computation of infiltration equation; ( $\mathrm{a}$ and $\mathrm{K}$ ) parameters by measuring the advance time to half furrow length $\left(T_{0.5 \mathrm{~L}}\right)$ and advance time to furrow length $\left(T_{\mathrm{L}}\right)$ and the model estimate the volume of water applied to half furrow length $\left(\mathrm{V}_{\mathrm{L}}\right)$; volume of water applied to furrow length $\left(\mathrm{V}_{0.5 \mathrm{~L}}\right)$ and subsurface shape factor; $\sigma_{\mathrm{Z}}$.

$$
\begin{aligned}
& \mathrm{a}=\left(\log \left(\mathrm{V}_{\mathrm{L}} / \mathrm{V}_{0.5 \mathrm{~L}}\right)\right) /\left(\log \left(\mathrm{T}_{\mathrm{L}} / \mathrm{T}_{0.5 \mathrm{~L}}\right)\right) \\
& \sigma_{\mathrm{Z}}=(\mathrm{a}+\mathrm{r}(1-\mathrm{a})+1) /((1+\mathrm{a})(1+\mathrm{r}))
\end{aligned}
$$

- Computation of the time required $\left(T_{\text {req }}\right)$ to achieve the required depth $\left(Z_{\text {req }}\right)$ : The basic mathematical model of infiltration is the modified Kostiakov function:

$$
\mathrm{Z}=\mathrm{KT}^{\mathrm{a}}+\mathrm{CT}
$$

Where $Z$ is the accumulated intake in volume per unit length; $\left(\mathrm{m}^{3} / \mathrm{m}\right)$ (per furrow or per unit width are implied); $T$ is the intake opportunity time in minutes; $a$ is the constant exponent; $K$ is the constant coefficient $\left(\mathrm{m}^{3} / \mathrm{min} / \mathrm{m}\right)$ of length; and $C$ is the basic intake rate; $\left(\mathrm{m}^{3} / \mathrm{min} / \mathrm{m}\right)$ of length. In order to express intake as a depth of application; $\mathrm{Z}$ must be divided by the unit width. For furrows; the unit width is the furrow spacing; $W_{f}$. Values of $K ; a ; b$ and $W_{f}$ along with the volume per unit length required to refill the root zone; $Z_{\text {req; }}$ are design input data. The design procedure requires that the intake opportunity time associated with $Z_{\text {req }}$ be known. This time; represented by $T_{\text {req; }}$ requires a nonlinear solution to Eq. (11): 


$$
\mathrm{T}_{\text {req }}=\left(\mathrm{Z}_{\text {req }} / \mathrm{K}\right)^{(1 / \mathrm{a})}
$$

- Computation and predictions of advance time: The time required for water to cover the field; the advance time; $\mathrm{T}_{\mathrm{L}}$; necessitates evaluation or at least approximation of the advance trajectory. Input data include the inflow discharge; $\left(Q_{f}\right)$; the field length; $(\mathrm{L})$; the infiltration coefficients $(\mathrm{K}$; $\mathrm{a}$; and $\mathrm{C})$; the field slope; $\left(\mathrm{S}_{\mathrm{o}}\right)$; and the flow crosssection area $\left(A_{0}\right)$ based on the cross-section geometry parameters $\left(P_{1}\right.$ and $\left.P_{2}\right)$.

1. The first step is to make an initial estimate of its value and label this value $E_{1}$; then; a revised estimate of $E_{1}$ is computed and compared below.

2. Calculate the subsurface shape factor; $\sigma_{z}$; from the following equation:

$$
\sigma_{\mathrm{Z}}=\left(\mathrm{a}+\mathrm{E}_{1}(1-\mathrm{a})+1\right) /\left((1+\mathrm{a})\left(1+\mathrm{E}_{1}\right)\right)
$$

3. Calculate the time of advance; $T_{L} ;$ using the following Newton-Raphson procedure:

a. Assume an initial estimate of $\left(T_{L}\right)$ as $\left(T_{1}\right)$.

$$
\mathrm{T}_{1}=5 \times \mathrm{A}_{\mathrm{o}} \times \mathrm{Y} / \mathrm{Q}_{\mathrm{f}}
$$

b. Compute a revised estimate of $\left(T_{L}\right)\left(T_{2}\right)$ as:

$$
\mathrm{T}_{2}=\mathrm{T}_{1}-\left[\frac{\mathrm{Q}_{\mathrm{o}}-\sigma_{\mathrm{y}} \mathrm{A}_{\mathrm{o}} \mathrm{L}-\sigma_{\mathrm{z}} \mathrm{kT}^{\mathrm{a}} \mathrm{LW}_{\mathrm{f}}-\left(\mathrm{f}_{\mathrm{o}} \mathrm{T} \mathrm{W} \mathrm{W}_{\mathrm{f}} /(1+\mathrm{r})\right)}{\mathrm{Q}_{\mathrm{o}}-\left(\sigma_{\mathrm{z}} \mathrm{ak} \mathrm{W} \mathrm{W}_{\mathrm{f}} / \mathrm{T}^{1-\mathrm{a}}\right)-\left(\mathrm{f}_{\mathrm{o}} \mathrm{LW}_{\mathrm{f}} /(1+\mathrm{r})\right)}\right]
$$

c. Compare the initial $\left(T_{1}\right)$ and revised $\left(T_{2}\right)$ estimates of $\left(T_{L}\right)$. If they are within about $5 \times 10^{-7}$ minutes or less; then the analysis proceeds to step 4 . If they are not equal; let $\left(T_{1}=T_{2}\right)$ and repeat steps $b$ through $c$.

4. Compute the time of advance to the field midpoint; $\left(T_{0.5 L}\right)$; using the same procedure as outlined in step 3 . The half-length; $(0.5 \mathrm{~L})$ is substituted for $(L)$ and $(T$ $0.5 \mathrm{~L})$ for $\left(T_{L}\right)$.

5. Compute a revised estimate of $E_{2}$ as follows:

$$
\mathrm{E}_{2}=\log \left(\mathrm{T}_{\mathrm{L}} / \mathrm{T}_{0.5 \mathrm{~L}}\right) / \log \left(\mathrm{T}_{0.5 \mathrm{~L}} / \mathrm{T}_{\mathrm{L}}\right)
$$

6. Compare the initial estimate; $E_{1}$; with the revised estimate; $E_{2}$. The differences between the two should be less than $5 \times 10^{-7}$. If they are equal; the procedure for finding $T_{L}$ is concluded. If not; let $E_{1}=E_{2}$ and repeat steps 2-6.

- Calculation of volume balance advance equation may be stated as:

$$
\begin{aligned}
& \mathrm{r}=\log \left(\mathrm{L}_{0.5 \mathrm{~L}} / \mathrm{L}_{\mathrm{L}}\right) / \log \left(\mathrm{T}_{0.5 \mathrm{~L}} / \mathrm{T}_{\mathrm{L}}\right) \\
& \mathrm{xr}=\mathrm{L}_{\mathrm{L}} / \mathrm{T}_{\mathrm{L}}^{\mathrm{r}} \\
& \mathrm{T}=(\mathrm{X} / \mathrm{xr})^{1 / \mathrm{r}}
\end{aligned}
$$

- Computation of cutoff time; $T_{\text {co1 }}$; from the following equation:

$$
\mathrm{T}_{\mathrm{CO} 1}=\mathrm{T}_{\mathrm{L}}+\mathrm{T}_{\text {req }}
$$


- Computation of recession time $\mathrm{T}_{\text {reci }}$ from the following equation:

$$
\mathrm{T}_{\text {rec }}=\mathrm{T}_{\mathrm{CO} 1}
$$

- Computation of water volume added (applied) to soil Volin according to $\mathrm{T}_{\text {coli }}$; from the following equation:

$$
\mathrm{Vol}_{\text {in }}=\mathrm{Q}_{\mathrm{f}} \mathrm{T}_{\mathrm{CO} 1}
$$

- Computation of opportunity time; $\mathrm{T}_{\text {opp }}$ from the following equation:

$$
\mathrm{T}_{\text {OPP }}=\mathrm{T}_{\text {rec }}-\mathrm{T}_{\mathrm{adv}}
$$

- Computation of water infiltrated depth; $Z_{\text {inf }}$ from the following equation:

$$
\mathrm{Z}_{\text {inf }}=\mathrm{KT}^{\mathrm{a}}+\mathrm{CT}
$$

- Computation of recession time; $T_{\text {rec }}$ from the following equation:

$$
\mathrm{T}_{\text {rec }}=\mathrm{T}_{\mathrm{OPP}}+\mathrm{T}_{\mathrm{adv}}
$$

- Computation of water infiltrated volume for each $\mathrm{I}^{\text {st }}$ distance (station); $\mathrm{V}_{\text {inf }}$ from the following equation:

$$
\mathrm{V}_{\mathrm{inf}}=\left(\left(\mathrm{Z}_{\mathrm{inf}}(\mathrm{I})+\mathrm{Z}_{\mathrm{inf}}(\mathrm{I}-1)\right) / 2\right) \mathrm{X}(\mathrm{I})
$$

\section{Model output:}

- Computation of total infiltrated depth (Tid); from the following equation:

$$
\mathrm{Tid}=\sum_{\mathrm{i}=1}^{\mathrm{i}=\mathrm{N}} \mathrm{V}_{\mathrm{inf}} / \mathrm{L}
$$

Where: $\mathrm{N}$ : number of stations

- Computation of runoff volume; (Rov); from the following equation:

$$
\text { Rov }=\mathrm{Vol}_{\text {in }}-\sum_{\mathrm{i}=1}^{\mathrm{i}=\mathrm{N}} \mathrm{V}_{\text {inf }}
$$

- Computation of runoff depth; (Rod); from the following equation:

$\operatorname{Rod}=\operatorname{Rov} / \mathrm{L}$

- Computation of total infiltrated volume percent; (Tivp) from the following equation:

$$
\operatorname{Tivp}=\sum_{\mathrm{i}=1}^{\mathrm{i}=\mathrm{N}} \mathrm{V}_{\text {inf }} / \mathrm{Vol}_{\text {in }}
$$

- Computation of runoff percent; (Rop); from the following equation:

$$
\mathrm{Rop}=\mathrm{Rov} / \mathrm{Vol}_{\text {in }}
$$


- The application efficiency was calculated as the ratio of the required water infiltrated depth $\left(Z_{\text {req }}\right)$ to the summation total water infiltrated depth plus runoff depth). Computation of application efficiency; $\left(E_{a}\right)$; from the following equation:

$$
\mathrm{E}_{\mathrm{a}}=\mathrm{Z}_{\mathrm{req}} /(\mathrm{Tid}+\mathrm{Rod})
$$

- Computation of water storage efficiency; $\left(E_{S}\right)$; from the following equation:

$$
\mathrm{E}_{\mathrm{S}}=\mathrm{Z}_{\text {req }} / \mathrm{Z}_{\text {ave }}
$$

- Computation of deep-percolation losses percent; (DP); from the following equation:

$\mathrm{DP}=\mathrm{Tivp} / \mathrm{Vol}_{\text {in }}$

- Computation of distribution uniformity; (DU); from the following equation:

$\mathrm{D}_{\mathrm{U}}=\mathrm{Z}_{\text {inf }} / \mathrm{Tid}$

\section{Performance calculation (adjust recession):}

- The same steps procedure were repeated using a new values of cutoff time; ( $\left.T_{\mathrm{CO} 2}\right)$; recession time; $\left(T_{\text {rec2 }}\right)$ and the total volume added to the soil; $\left(V_{\text {in2 }}\right)$ according to cutoff time; $\left(T_{\mathrm{CO} 2}\right)$ instead of old values of cutoff time; $\left(T_{\mathrm{CO} 1}\right)$; recession time; $\left(T_{\text {rec1 }}\right)$ and the total volume added to the soil; $\left(\mathrm{V}_{\mathrm{in} 1}\right)$ by using the following equations:

$$
\begin{aligned}
& \mathrm{T}_{\mathrm{CO} 2}=\mathrm{T}_{\text {req }}+\mathrm{T}_{\mathrm{L}}-\left(\sigma_{\mathrm{Y}} \mathrm{A}_{\mathrm{O}} \mathrm{L} / \mathrm{Q}_{\mathrm{f}}\right) \\
& \mathrm{V}_{\mathrm{in} 2}=\mathrm{Q}_{\mathrm{f}} \mathrm{T}_{\mathrm{CO} 2} \\
& \mathrm{~T}_{\mathrm{rec} 2}=\mathrm{T}_{\mathrm{CO} 2}+\left(\mathrm{T}_{\mathrm{CO} 1}-\mathrm{T}_{\mathrm{CO} 2}\right)(\Delta \mathrm{X} / \mathrm{L})
\end{aligned}
$$

Where: $\Delta \mathrm{X}$ : station distance; (5 meter interval).

\section{Filed Experiments:}

Field experiments were conducted at a sugar crops research stationAlexandria in clay soil during summer irrigation season of 2013-2014 to test the accuracy of the developed model with the experimental work measurements data. Used data included all hydraulic phases of surface irrigation in long furrow.

\section{Field measurements:}

Soil samples were collected from several different randomized locations to represent the whole experimental site at $20 \mathrm{~cm}$ increments to a depth of $60 \mathrm{~cm}$; to determine some physical and hydraulic properties. Average of some soil characteristics are shown in Table (2).Double ring infiltrometer was used to determine soil infiltration rate. Soil roughness and furrows cross section area was determined using a pin -type profile-meter; which consisted of a series of 19 movable iron rods; spaced $50 \mathrm{~mm}$ apart. At each station; the rods were lowered until they touched the soil surface. The individual scales on the rods of the profile-meter provided data to plot furrow depth; $(Y)$; as function of the lateral distance. Measurements of furrow irrigation hydraulic parameters included furrow length and width; slope; water 
application rate; advance and recession times; furrow geometry; cut-off timeand furrow water normal depth with time through irrigation event for each inflow rate were recorded. The furrow length; width and the slope direction of water run were 70; 0.7 meter and; $0.1(\%)$; respectively.

\section{Inflow rate measurements:}

Furrows were irrigated using three different spiels diameters of $45.5 ; 60.15$ and $70(\mathrm{~mm})$ and $800 \mathrm{~mm}$ in length; which gave average three different water inflow rates of $1.22 ; 1.48$ and $2.37(\mathrm{l} / \mathrm{s})$; respectively based on changes of water head over the center of spiels $(h)$ and spiels diameter. The treatments were separated by nonirrigated furrows. Furrows adjacent to the furrow being monitored were irrigated simultaneously.

Table 2. Soil physical properties for experimental site.

\begin{tabular}{|c|c|c|c|c|c|c|c|c|}
\hline \multirow{2}{*}{$\begin{array}{l}\text { Soil } \\
\text { depth } \\
(\mathrm{cm})\end{array}$} & \multicolumn{3}{|c|}{ Particle size distribution;(\%) } & \multirow{2}{*}{$\begin{array}{c}\text { Soil } \\
\text { texture } \\
\text { class }\end{array}$} & \multirow{2}{*}{$\begin{array}{l}\text { Soil bulk } \\
\text { density } \\
\mathrm{g} \mathrm{cm}^{-3}\end{array}$} & \multirow{2}{*}{$\begin{array}{l}\text { P.W.P } \\
\mathrm{m}^{3} \mathrm{~m}^{-3}\end{array}$} & \multirow{2}{*}{$\begin{array}{c}\text { F.C } \\
\mathrm{m}^{3} \mathrm{~m}^{-3}\end{array}$} & \multirow{2}{*}{$\begin{array}{c}\text { Available } \\
\text { water } \\
\mathrm{m}^{3} \mathrm{~m}^{-3}\end{array}$} \\
\hline & Sand & Silt & Clay & & & & & \\
\hline $0-20$ & 22.25 & 22.63 & 55.12 & Clay & 1.31 & 0.263 & 0.398 & 0.135 \\
\hline $20-40$ & 21.79 & 22.88 & 55.33 & Clay & 1.34 & 0.273 & 0.412 & 0.139 \\
\hline $40-60$ & 21.28 & 22.87 & 55.85 & Clay & 1.36 & 0.280 & 0.421 & 0.141 \\
\hline
\end{tabular}

\section{P.W.P: Permanent welting point; F.C: field capacity}

This was done to prevent lateral seepage and to provide infiltration conditions similar to a typical furrow irrigation practice. The different furrow irrigation inflow rates $\left(Q_{f}\right)$ were calculated by the following equation according to Michael; (1978).

$$
\mathrm{Q}_{\mathrm{f}}=0.65 \times 10^{-3} \mathrm{a} \times \sqrt{2 \mathrm{gh}}
$$

Where $\mathrm{h}$ : water head above the center of spiels $(\mathrm{cm}) ; \mathrm{a}$ : the spiels cross-section area $\left(\mathrm{cm}^{2}\right)$ and $\mathrm{g}$ : acceleration due to gravity $\left(981 \mathrm{~cm} / \mathrm{sec}^{2}\right)$. The calibration of the spiels was carried out under the operation conditions using volume and time method.

\section{Advance and recession time measurements}

Furrow length was divided into 14 stations; the distance between each two stakes was equal to $5 \mathrm{~m}$ interval. All volume balance parameters were measured on three adjacent furrows. Fourteen stakes were arranged and installed in the center line of furrow at each station from the upstream to end of the furrow to record the advance; recession times and water heights during irrigation events. The most 
important field data are the advance rate; which can vary throughout the irrigation season as mentioned by Elliott and Walker (1982).

\section{Furrow geometry}

During furrow evaluation; the cross-sectional geometry was measured at furrow top; middle and bottom using measuring tab. The measurements were taken just before irrigation and three days after irrigation following the method suggested by Elliott and Walker (1982) and Walker and Busman (1990).

\section{RESULTS AND DISCUSSION}

\section{Model application}

Based on best values attained from field experiments; computer simulation design was developed using the Basic language. The model was then executed to determine the system calculations performance (adjust recession time) through the design limitations. The output design limitations of the furrow system were; the gross water application; the opportunity time; the average intake depth; the surface runoff; the deep percolation and the application efficiency. Iteration method was used by model to determine furrow water normal depth $(\mathrm{Y})$; which matches with furrow inflow rate $\left(\mathrm{Q}_{\mathrm{f}}\right)$. The normal depth for inflow rates of $1.22 ; 1.48$ and $2.37(\mathrm{I} / \mathrm{s})$ were; 0.0597 ; 0.0655 and $0.0817(\mathrm{~m})$; respectively. The upstream cross sectional flow area were $0.0131 ; 0.0151$ and $0.0215\left(\mathrm{~m}^{2}\right)$; under the same inflow rates; respectively. The furrow shape parameters values were depended on values of water normal depth; which were determined by model and summarized in Table (3) for all furrows used in this study under different inflow rates.

Furrow shape factor parameters assist in determining the furrow crosssectional area $\left(A_{0}\right)$; especially the values of $P_{1}$ and $P_{2}$. Also form furrow water normal depth; both of wetted perimeters $\left(W_{P}\right)$; Reynolds number $(R)$ and water top width $\left(T_{w}\right)$ can be estimated easily by the model. 
Table 3. Furrow shape factor parameters under different inflow rates.

\begin{tabular}{|c|c|c|c|c|c|c|c|c|c|c|c|}
\hline \multicolumn{12}{|c|}{$\mathrm{Q}=1.22 ;(\mathrm{l} / \mathrm{s})$} \\
\hline $\mathrm{a}_{1}$ & $\mathrm{a}_{2}$ & $a_{1}$ & $a_{2}$ & $b_{1}$ & $\mathrm{~b}_{2}$ & $P_{1}$ & $\mathrm{P}_{2}$ & $\mathrm{~S}_{1}$ & $\mathrm{~S}_{2}$ & $\mathrm{C}_{1}$ & $\mathrm{C}_{2}$ \\
\hline 0.005 & 1.460 & 0.080 & 0.629 & 0.081 & 0.654 & 0.534 & 1.368 & 0.049 & 1.629 & 1.405 & 0.715 \\
\hline \multicolumn{12}{|c|}{$\mathrm{Q}=1.48 ;(\mathrm{l} / \mathrm{s})$} \\
\hline $\mathrm{a}_{1}$ & $\mathrm{a}_{2}$ & $a_{1}$ & $a_{2}$ & $b_{1}$ & $\mathrm{~b}_{2}$ & $P_{1}$ & $\mathrm{P}_{2}$ & $\mathrm{~S}_{1}$ & $\mathrm{~S}_{2}$ & $\mathrm{C}_{1}$ & $\mathrm{C}_{2}$ \\
\hline 0.005 & 1.483 & 0.081 & 0.650 & 0.083 & 0.674 & 0.523 & 1.364 & 0.049 & 1.650 & 1.420 & 0.717 \\
\hline \multicolumn{12}{|c|}{$\mathrm{Q}=2.37 ;(\mathrm{l} / \mathrm{s})$} \\
\hline $\mathrm{a}_{1}$ & $a_{2}$ & $a_{1}$ & $a_{2}$ & $b_{1}$ & $b_{2}$ & $\mathrm{P}_{1}$ & $\mathrm{P}_{2}$ & $\mathrm{~S}_{1}$ & $\mathrm{~S}_{2}$ & $\mathrm{C}_{1}$ & $\mathrm{C}_{2}$ \\
\hline 0.006 & 1.537 & 0.086 & 0.697 & 0.089 & 0.720 & 0.502 & 1.354 & 0.050 & 1.697 & 1.456 & 0.723 \\
\hline
\end{tabular}

\section{Model validation and verification}

In order to validate the developed model; field experimental data were implemented to determine the accuracy of representative furrow design. It was done by comparing the calculated results and predicted output results. Model validation or verification was indentified in two steps. First: to test the developed model representation of reality and to discover facts about the model behavior in comparison with field measured data for furrow irrigation system design. It's made by comparing the field measured advance time to end of furrow run; $T_{\text {adv }}(\mathrm{min})$ with that estimated by the developed model. Second: to compare the developed model with recently developed and improved volume balance model of Clemmens; (2007); in order to explain the developed model structure and operation. This is made by statistical test of a set of evaluating parameters including: Advance time to field end; $T_{\text {adv }}(\min )$ at $\mathrm{T}_{\mathrm{L}}$ and at $\mathrm{T}_{0.5 \mathrm{~L}}$; cut off time; $\mathrm{T}_{\mathrm{co}}(\mathrm{min})$; application efficiency percent; Ea (\%); runoff volume percent; Ro (\%); deep-percolation losses percent; DP(\%); water storage efficiency; Es (\%); water distribution uniformity ;DU (\%) and recession time to end; $\mathrm{T}_{\text {rec }}(\min )$.

\section{Advance and recession times}

Advance times to half furrow length $\left(T_{0.5 \mathrm{~L}}\right)$ and total furrow length $\left(T_{L}\right)$ were measured under three inflow rates of $1.22 ; 1.48$ and $2.37(\mathrm{l} / \mathrm{s})$. These values were;(21.6 and 76.8); (19.4 and 56.9) and (15.7 and 38.2) ( $\mathrm{min}$ ); respectively. While; Advance times to half furrow length $\left(T_{0.5 L}\right)$ and total furrow length $\left(T_{L}\right)$ were estimated by the model using Newton-Raphson procedure for the same inflow rates; were (21.63and 76.85); (19.42 and 56.94) and (15.71 and 38.21) ( $\mathrm{min})$; respectively. The duration to cutoff time was 106.59; 78.34 and 52.11 ( $\mathrm{min}$ ). The measured versus predicted results of advance time are presented graphically in Figs. (1a; 1c and 1e). Comparing the model prediction with field investigation; it can be seen that the model provided a good agreement with the field observations. The measured versus 
predicted results of recession times are presented graphically in Figs. (1b; $1 \mathrm{~d}$ and 1f). Comparing the model prediction with field investigation; it can be seen that the model in some instances slightly underestimated or overestimated the recession process. This deviation can be considered reasonable limits for a long the furrow's length.

\section{Water infiltrated depth and volume}

The parameters ( $\mathrm{a}$ and $\mathrm{K}$ ) of the water infiltrated depth equations were estimated and developed by the model under different inflow rates; by knowing both of: water inflow rate $\left(Q_{f}\right)$; upstream cross sectional flow area $\left(A_{0}\right)$; advance times to half furrow length $\left(T_{0.5 \mathrm{~L}}\right)$; total furrow length $\left(T_{\mathrm{L}}\right)$; volume of water applied to half furrow length; and volume of water applied to total furrow length. The value of $C$ was equal zero. Cumulative water infiltrated depth equations were; $Z=8.842 \mathrm{~T}^{0.544}$; $Z=13.490 \mathrm{~T}^{0.440}$ and $Z=26.910 \mathrm{~T}^{0.286}$ under three inflow rates; $1.22 ; 1.48$ and 2.37 $(\mathrm{I} / \mathrm{s})$; respectively. Water infiltrated depth for entire furrow for each flow condition were estimated by the model before performance calculation and were ranged between (114.45-60.0); (96.23-60.0) and (84.61-60.0) ( $\mathrm{mm})$ and after performance calculation (adjusting recession time); and were ranged between (109.03-60.0); (91.70-60.0) and (80.88-60.0) (mm) for $1.22 ; 1.48$ and 2.37 (l/s)as shown in Figs.(2a; $2 \mathrm{c}$ and $2 \mathrm{e})$; respectively. This is may be due to when using small inflow rate; the opportunity time for infiltrated water inside the soil layers in the vertical direction greater than water advance in horizontal direction. The results showed that water infiltrated depth fall relatively very close to $45^{\circ}$ line for inflow rate $1.48 ;(\mathrm{l} / \mathrm{s})$. Meanwhile; water infiltrated depth for inflow rates 1.22 and 2.37 ; $(\mathrm{I} / \mathrm{s})$; fall close to $45^{\circ}$ line with slightly deviation than the water infiltrated depth values. Water infiltration rate parameters ( $\mathrm{a}$ and $\mathrm{K}$ ) equations estimated and developed by the model were; $\mathrm{I}=288.603 \mathrm{~T}^{-0.456} ; \mathrm{I}=356.189 \mathrm{~T}^{-0.560}$ and $\mathrm{I}=462.26 .693 \mathrm{~T}^{-0.732}$ under the same inflow rates; respectively.

Water infiltrated volume for entire furrow for each flow condition were estimated by the model before performance calculation and were ranged between (0.572-322); (0.481-0.313) and (0.423-0.308) $\left(\mathrm{m}^{3}\right)$ and after performance calculation (adjusting recession time); and were ranged between (0.545-0.321); (0.459-0.312) and (0.404$0.307)\left(\mathrm{m}^{3}\right)$ as shown in Fig; (2b; $2 \mathrm{~d}$ and $\left.2 \mathrm{f}\right)$; for $1.22 ; 1.48$ and $2.37(\mathrm{l} / \mathrm{s})$; respectively. As shown in Figs. ( $2 \mathrm{~b} ; 2 \mathrm{~d}$ and $2 \mathrm{f}$ ); it is clear from the estimated data; the model predictions are in a good agreement with the field observations especially with inflow rate $1.48(\mathrm{l} / \mathrm{s})$. While; slightly over predicted the water infiltrated volume for inflow rate of 1.22 and $2.37(\mathrm{l} / \mathrm{s})$; respectively. The results revealed that the average error percent between field observations and predicted program output results were ranged between (2.24 to $3.46 \%$ ) and (1.93 to $3.0 \%$ ) for water infiltrated depth $\left(\mathrm{Z}_{\text {inf }}\right)$; and water infiltrated volume $\left(\mathrm{V}_{\text {inf }}\right)$ under three inflow rates; $1.22 ; 1.48$ and 2.37 
$(\mathrm{I} / \mathrm{s})$; respectively. Therefore; we can conclude that the model is capable of predicting water infiltrated depth and volume and estimating the parameters of the water infiltration equations under field conditions.

\section{Runoff volume losses}

Applying equation 25; the values of runoff volume were decreased for all inflow rates used as furrow length increased from near 0 to $70 \mathrm{~m}$. As shown in Fig. (3a); the values of runoff volume are intersected at $30 \mathrm{~m}$; and relatively the same value; $4.203 ; 4.204$ and $4.279\left(\mathrm{~m}^{3}\right)$ for inflow rates; $1.22 ; 1.48$ and $2.37(\mathrm{l} / \mathrm{s})$; respectively. The overall values of water runoff volume were estimated before performance calculation (adjusting recession time); were $0.729 ; 1.357$ and $2.076\left(\mathrm{~m}^{3}\right)$ While; after performance calculation (adjusting recession time) were; $0.814 ; 1.216$ and $1.519\left(\mathrm{~m}^{3}\right)$ under three inflow rates; $1.22 ; 1.48$ and $2.37(\mathrm{l} / \mathrm{s})$; respectively. Using the equation 28; it is clear from the results presented in Fig. (3b); runoff losses percent were decreased for all inflow rates used as furrow length increased from near 0 to $70 \mathrm{~m}$; and improved after performance calculation (adjusting recession time). These values were ranged between (92.64-10.99); (93.35-17.64) and (93.93-22.86) (\%) under three inflow rates; $1.22 ; 1.48$ and $2.37(\mathrm{l} / \mathrm{s})$; respectively.

\section{Deep-percolation losses}

As shown in Fig. (3c); the values of deep-percolation losses percent; estimated using the equation 31; were decreased for all inflow rates used as furrow length increased from near0 to $50 \mathrm{~m}$; then after this length the values of deeppercolation losses percent were slightly increased. This is because of the temporal and spatial variation of infiltration rate of the soil is responsible for non-uniformity of water distribution along the length of furrow irrigation; also the water excess were collected after cutoff time at the last $20 \mathrm{~m}$; so the water infiltrated inside the soil will penetrated to deeper depth. The overall values of deep-percolation losses percent were estimated before performance calculation (adjusting recession time) were; $39.12 ; 27.70$ and 19.31 (\%) under three inflow rates; $1.22 ; 1.48$ and $2.37(\mathrm{I} / \mathrm{s})$; respectively. While; after performance calculation (adjusting recession time) were; $32.30 ; 21.39$ and 13.92 (\%) under the same inflow rates; respectively. It is clear from the results that the deep-percolation losses percent were decreased and improved after performance calculation (adjusting recession time); and the model accurately predicting deep percolation losses along the furrow length under different field conditions.

\section{Water storage efficiency}

By applicability of equation30; water storage efficiency relates to the volume of water stored in the root zone (defined by $Z_{\text {req }}$ ) to meet the crop water needs in relation to the total storage capacity of the root zone. Water storage efficiency values were decreased with increasing furrow length under all used inflow rates. This is may be due to the opportunity time for infiltrated water at furrow inlet much larger than at furrow end. Figure (3d); showed that; the values of water storage efficiency values 
were intersected at $45 \mathrm{~m}$ from the beginning of furrow length; and are nearly the same value; $91.10 ; 90.90$ and 91.20 (\%) for inflow rates; $1.22 ; 1.48$ and $2.37(\mathrm{l} / \mathrm{s})$; respectively. This may be due to the moisture contents inside the soil are equal at this distance for all the inflow rates used and reached to field capacity. High water storage efficiency means that; the irrigation brings the soil root zone to field capacity; but does not lead to deep-percolation.

\section{Water distribution uniformity}

Using the equation 32; water distribution uniformity is defined as the average infiltrated depth in the lowest quarter of the field; divided by the average infiltrated depth in the field. Water distribution uniformity gives an indication of the magnitude of the distribution problem. As shown in Fig. (3e); water distribution uniformity values decreased with increasing furrow length for all inflow rates used; and take the same trend curves of water storage efficiency; Fig. (3d).Also as shown in figure (3e); water distribution uniformity values were intersected at $45 \mathrm{~m}$ from the beginning of furrow length; and are nearly the same value; $96.94 ; 96.98$ and 97.47 (\%) for inflow rates of1.22; 1.48 and $2.37(\mathrm{I} / \mathrm{s})$; respectively.

\section{Application efficiency}

The application of the equation 29; results showed that; the highest value of application efficiency of $63.22 \%$ was obtained with inflow rate of 2.37 (l/s); meanwhile; the lowest value of application efficiency of $56.71 \%$ was obtain with inflow rate of $1.22(\mathrm{l} / \mathrm{s})$. Maximum value of application efficiency $60.46 \%$ was obtained with inflow rate $1.22(\mathrm{l} / \mathrm{s})$ at furrow length $55 \mathrm{~m}$; after this length the value of application efficiency reduced by $4.33 \%$. Also; maximum value of application efficiency $61.06 \%$ was obtained with inflow rate $1.48(\mathrm{l} / \mathrm{s})$ at furrow length $65 \mathrm{~m}$. after this length the application efficiency reduced by $0.91 \%$. Fig. (3f); represents the relationship between the furrow length from near 0 to $70 \mathrm{~m}$ and the values of water application efficiency for selected furrows used for the model calculations. This figure; illustrates that high efficiencies can be achieved for small furrow lengths with relatively low or medium furrow inflow rates; and alternatively; larger furrow inflow rates are needed as furrow length increases to obtain high efficiencies. Fig. (3f), showed that; the values of water application efficiency are intersected at $60 \mathrm{~m}$; and are nearly the same value; 60.46; 59.95 and $59.02 \%$ for inflow rates; $1.22 ; 1.48$ and $2.37(\mathrm{l} / \mathrm{s})$; respectively. 


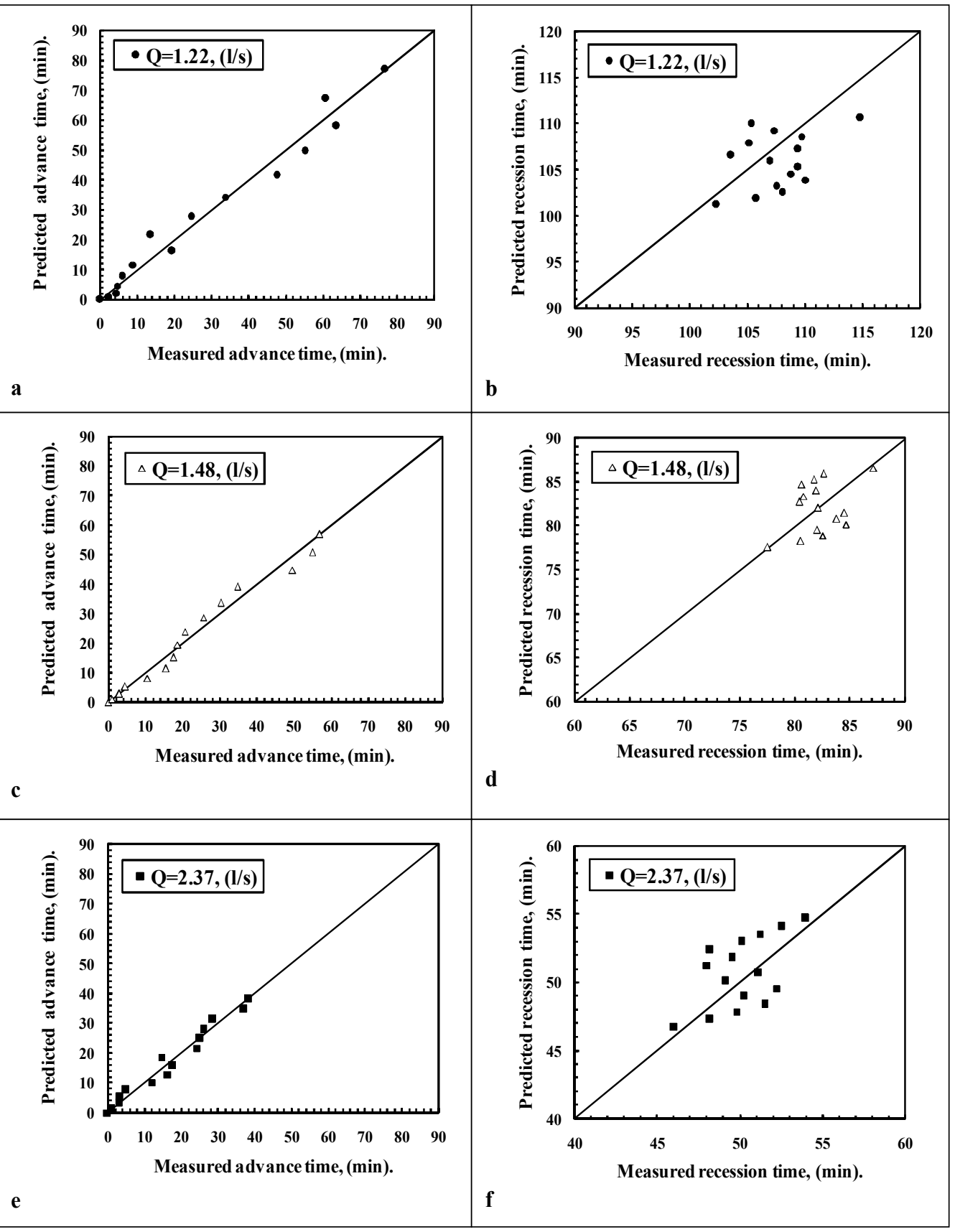

Fig. 1. Measured versus predicted results of advance and recession times.

This means that; the length of the furrow should not be exceeded than $60 \mathrm{~m}$ with the inflow rates used. Water application efficiency was found to increase with decreasing cut-off time from 101.17 to 46.72 ( $\mathrm{min}$ ) as water discharge increased from 1.22 to $2.37(\mathrm{I} / \mathrm{s})$. At this distance $(60 \mathrm{~m})$ water applied would have been saved in irrigated furrows by $26.57 ; 29.48(\%)$ for inflow rates; $1.22 ; 1.48$ and $2.37(\mathrm{l} / \mathrm{s})$; respectively. These results indicate that significant improvements in irrigation efficiency could be achieved through the adoption of design and management 
practices that are appropriate to meet the farm's environmental and management constraints.
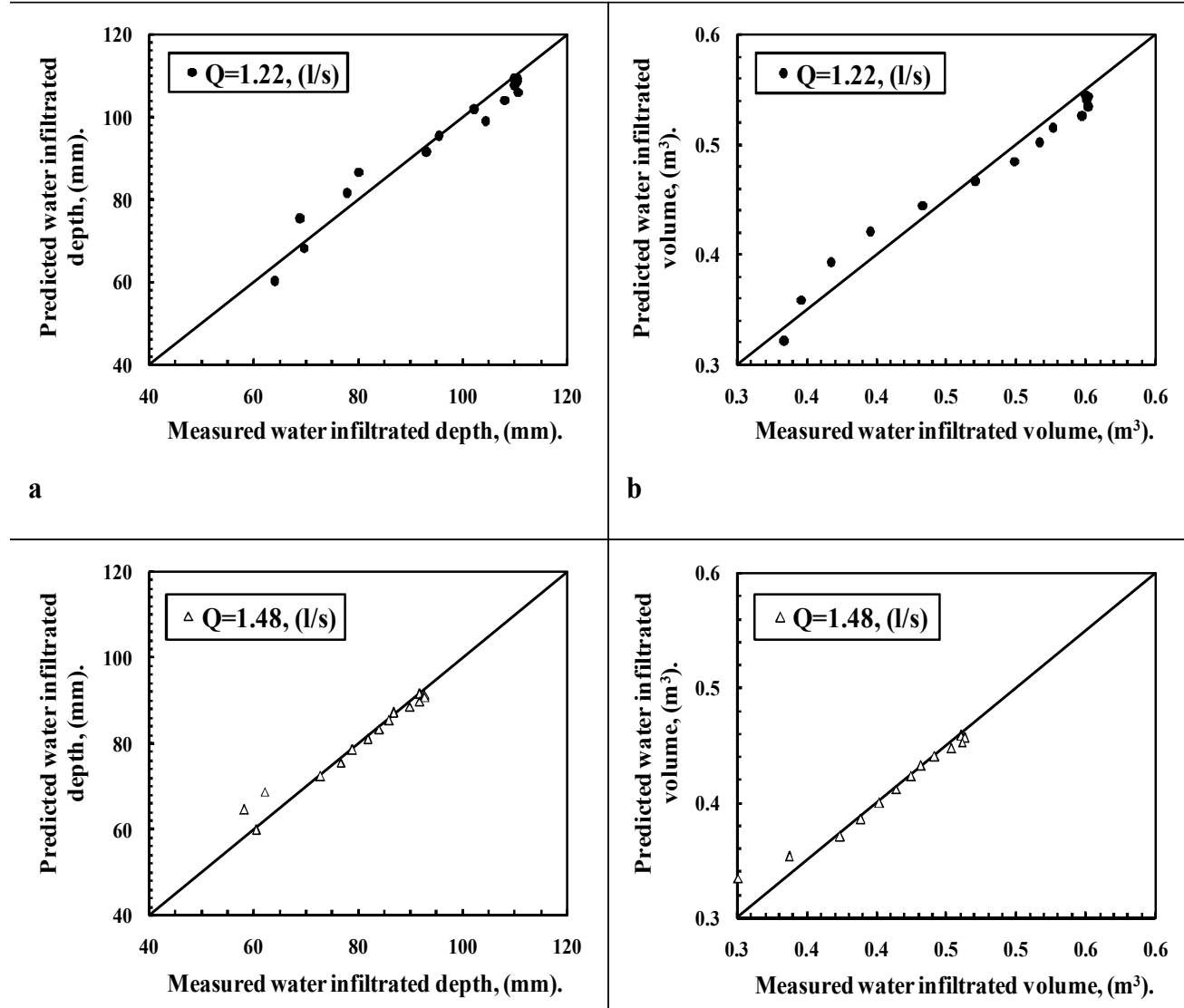

b
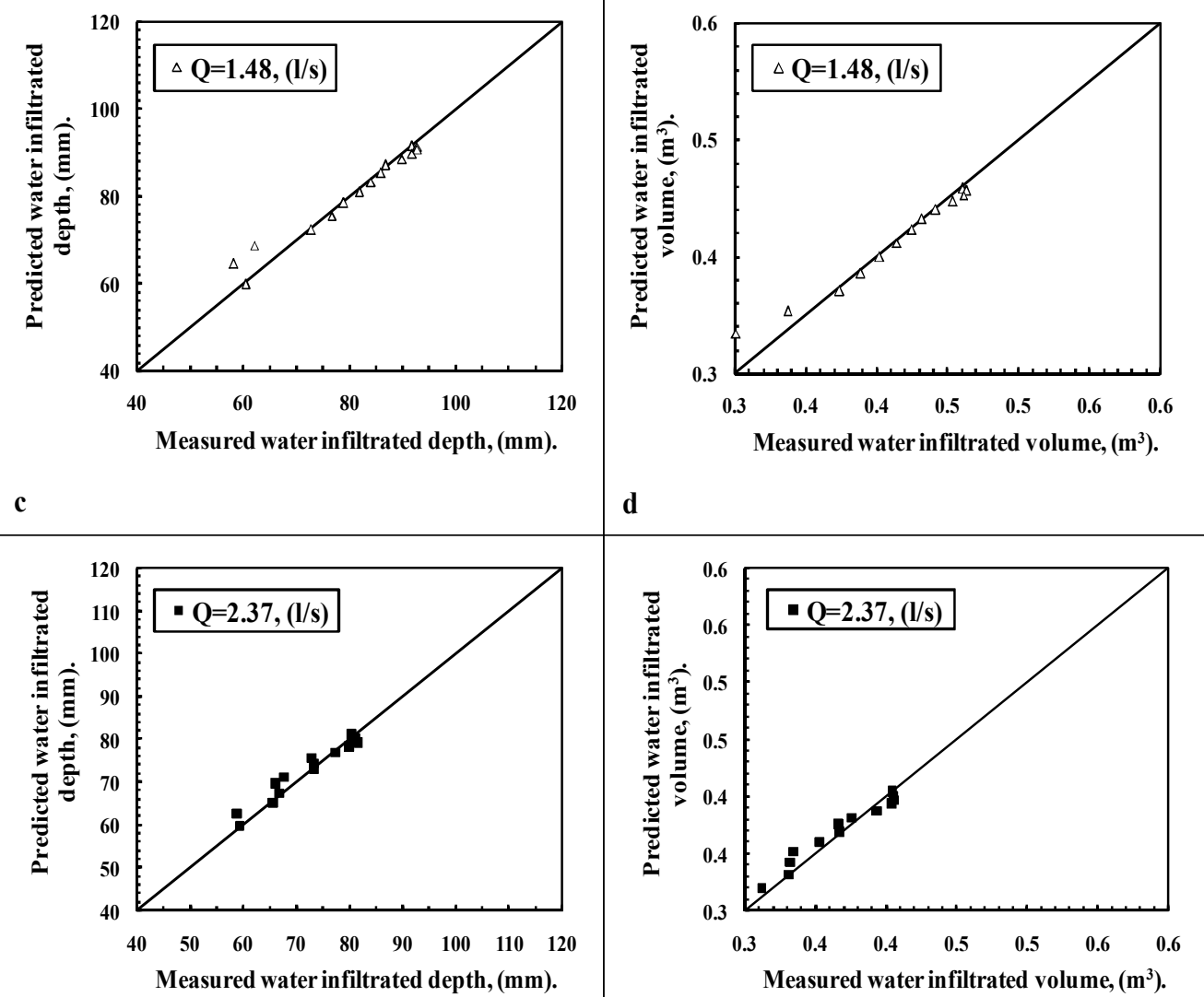

d

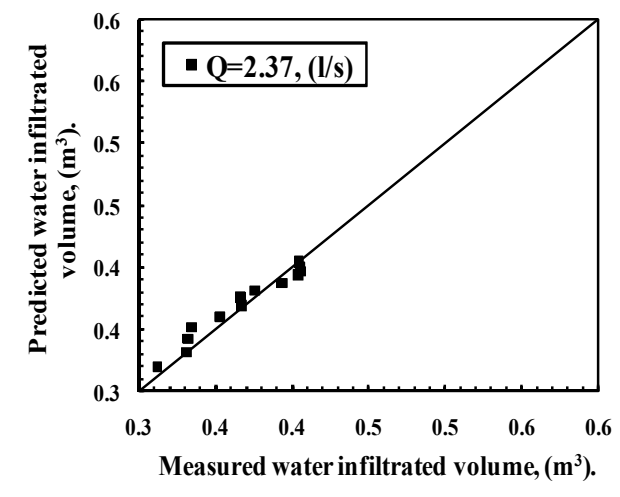

e

f

Fig. 2. Measured versus predicted results of water infiltrated depth and volume.

Higher furrow irrigation inflow rate 2.37; (I/s) gave higher value of water application efficiency; this results agreed with Kassem and El Khatib (2000); who mentioned that increasing furrow irrigation inflow rate from 0.7 to $2.1(\mathrm{l} / \mathrm{s})$ results in increasing water application efficiency from 67.22 to $71.6 \%$ at furrow length $50 \mathrm{~m}$ in 
clay soil. However; the higher values of water application efficiency mean less deep percolation losses and runoff losses. Figure (3f); can be used to determine where this change in trend occurs in order to achieve an optimal furrow length given a furrow inflow. The variations between $\left(E_{a} ; \%\right)$ values at irrigation runs may be due to opportunity times; so; the inflow rate play a main role in improving the $\left(E_{a}\right)$.this trend is agree with Abd el Wahab (2005); Ali et. al. (2009) and Fabio et. al.; (2002).

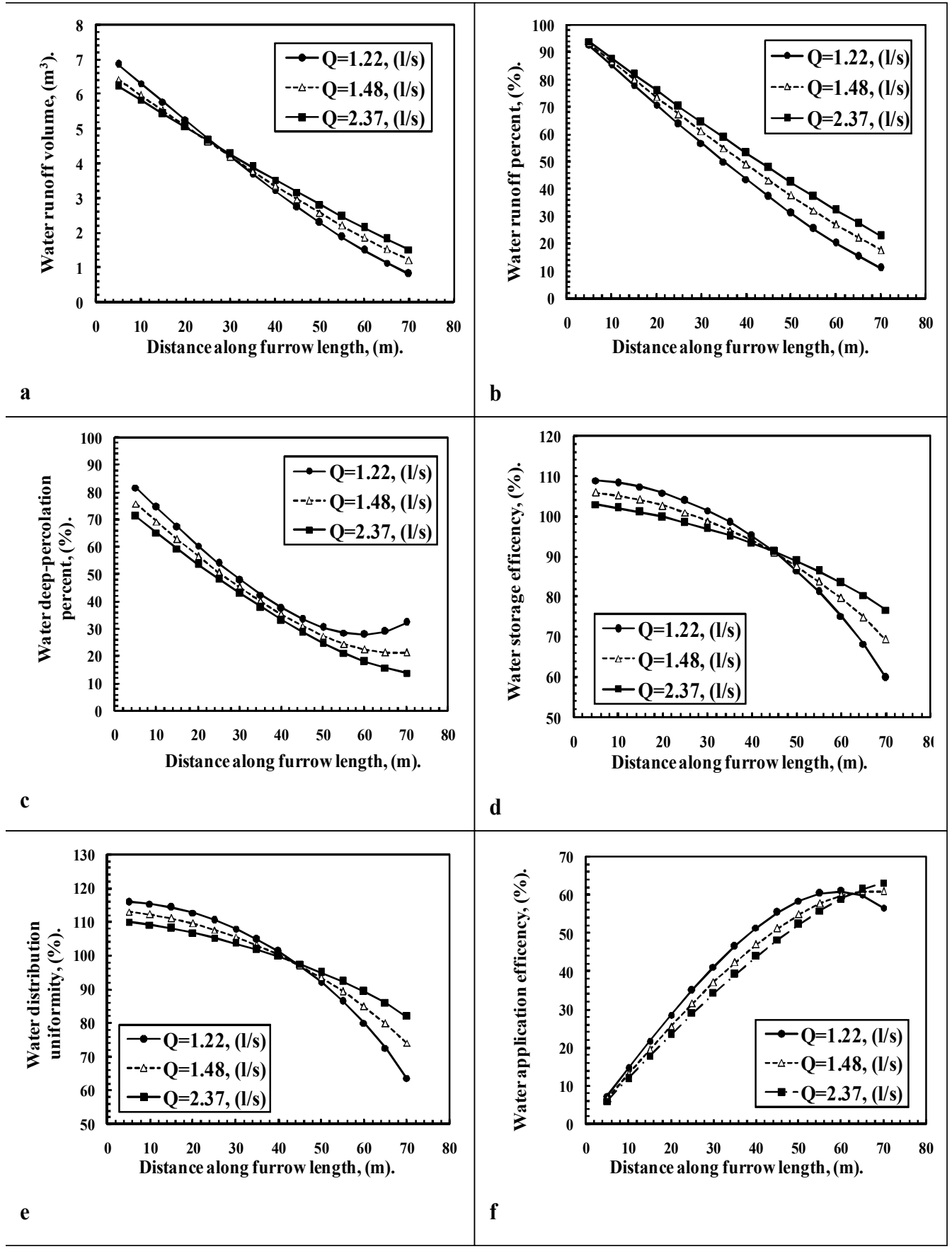

Fig. 3. predicted results of (Rov; $\left.\mathrm{m}^{3}\right)$ (Ro; \%); (DP; \%); (Es; \%); (DU; \%) and (Ea; \%). 
Fig. (3f); can be used to guide farmers with similar clay soil types to select the optimal length and inflow rate of their furrow system. Based on the size of the field; the farmer can select which furrow inflow will produce the desired efficiency; or alternatively what furrow lengths could be used for a given furrow inflow. However as discussed previously; given a choice; higher furrow inflows and longer furrow lengths have the advantage of lower installation and maintenance costs and require less accuracy in furrow inflow application while at the same time producing only small reductions in efficiencies.

Total water infiltrated volume percent; (Tivp; \%); application efficiency percent; (Ea; $\%)$; runoff volume percent; (Ro; \%); deep-percolation losses percent; (DP \%); water storage efficiency; $\left(E_{S} ; \%\right)$ and water distribution uniformity (DU; \%) were determined from field data measurements for furrow irrigation system design after performance calculations; (adjust recession) under flow rates 1.22; 1.48 and 2.37 $(\mathrm{I} / \mathrm{s})$; these values were summarized in Table (4). It is clear that; the values of the output performance parameters (Tivp; \%); (Ea; \%); (Ro; \%); (DP \%); (Es; \%) and (DU; \%) were improved after performance calculations (adjusting recession time).

Table 4. Output model results after performance calculations; (adjust recession) underthree inflow rates.

\begin{tabular}{|c|c|c|c|c|c|c|c|}
\hline & Adjust & Tivp; (\%) & $E_{a} ;(\%)$ & Ro; (\%) & DP; (\%) & $E_{S} ;(\%)$ & DU; (\%) \\
\hline $1.22 ;(\mathrm{l} / \mathrm{s})$ & After & 89.01 & 56.71 & 10.99 & 32.29 & 59.88 & 63.72 \\
\hline $1.48 ;(\mathrm{l} / \mathrm{s})$ & After & 82.36 & 60.97 & 17.64 & 21.39 & 69.39 & 74.40 \\
\hline $2.37 ;(\mathrm{l} / \mathrm{s})$ & After & 77.14 & 63.22 & 22.86 & 13.92 & 76.69 & 81.19 \\
\hline
\end{tabular}

\section{CONCLUSION}

Mathematical model was developed for furrow surface irrigation design using BASIC language to simulate all stages of the hydraulic movement of water and evaluate the performance of accounts design surface irrigation lines as well as to assess alternative designs for field and administrative operations. The developed model was based on the volume balance method considering the target application depth which solved by the Newton-Raphson procedure. Model performance was evaluated and verified using field data. Based on the results obtained in this study; the following conclusions can be summarized as follows:

1-The developed mathematical model is capable to select which furrow shape used and simulating furrow surface flow; and accurately predicting advance and recession times; water infiltrated depth and volume; runoff and deep-percolation losses; Water storage and application efficiency . 
2-The model accurately predicted the ( $\mathrm{a}$ and $\mathrm{K}$ ) parameters for the infiltration rate and water infiltrated depth and volume equations for any inflow rate used.

3-The proposed methodology is computationally efficient and can help irrigation consultants in the design of furrow irrigation system to increase application efficiency and to save water and conserve water and soil as well as the economical utilization of power.

\section{REFERENCES}

1. Abdel Wahab; D.M. 2005. Evaluation; Prediction and optimization of long furrow irrigation under Kenana conditions. PhD Thesis Dissertation; water Management and irrigation Institute; University of Gezira; Wad Medani; Sudan.

2. Ali; M. S. M.; A. B. Saeed and M. A. Mustafa. 2009. Appraisal of spatial and temporal variation of the soil moisture profile in the long furrow irrigation system in Kenana Sugarcane Plantation. Science and TechnologyJournal; Sudan University of Science and Technology 10 (1) 71-81.

3. Clemmens; A.J. 2007. Simple approach to surface irrigation design: Spreadsheet applications Sakia.org e-publish; http://www.sakia. Org/ejlw; Land and Water; e-J. $1: 20-43$.

4. Eldeiry; A.; L.Garcia; A. S. A.Ei-Zaher and M.El-SherbiniKiwan. 2005. Furrow Irrigation System Design for Clay Soils in Arid Regions. Appl. Eng. Agric.; 21(3): 411- 420.

5. Elliott; R.L. and W. R.Walker. 1982. Field evaluation of furrow infiltration advance functions. Trans. Of the ASAE; 25; 396-400.

6. Fabio; M. S.; A. A. Campos; L. S. Pereira; J. M. Goncalves; Y. N. Li; Z. Mao and B. Dong;2002. Improvement of basin irrigation for water saving and salinity control in the Yalow River Basin China. In Pap No: 022258; ASAE. Annual Int. Meeting Chicago; Illinois;USA; July; 28-31.

7. Gillies; M. H.;R. J. Smith and S. R.Raine. 2008. Measurement and Management of Furrow Irrigation at the Field Scale. Irrigation Australia 2008-Share the Water; Share the Benefits: Irrigation Australia National Conference and Exhibition; Melbourne; Australia. http://eprints.usq.edu.au/4160/.

8. Hamed;E. and L. Abdolmajid. 2011. Field Evaluation of Various Mathematical Models for Furrow and Border Irrigation Systems. Soil and Water Res.; 6 (2): 91101.

9. Kassem; M. A. and S. I. El Khatib. 2000. Mathematical determination of the effect of the major engineering factors on the efficiency of long furrows irrigation for corn crop. Misr J. Ag. Eng.; 17 (3): 569-588. 
10. Ma; J. J.; X. H.Sun; X. H.Guo and Y. F.Li.; 2010. Multi-objective Fuzzy Optimization Model for Border Irrigation Technical Parameters. J. Drain. Irrig. Mach. Eng.; 28(2):160-163;178.

11. Michael; A.M. 1978. Irrigation theory and practice. $1^{\text {st }}$ ed.; New Delhi.

12. Navabian; M.; A. M. Liaghat; R. J. Smith; and F. Abbasi; 2009. Empirical Functions for Dependent Variables in Cutback Furrow Irrigation. Irrig. Sci.; 27(3):215-222.

13. Nelson; D. J. and M. M. Al-Kaisi. 2011. Agronomic and economic evaluation of various furrow irrigation strategies for corn production under limited water supply. soil and water conservation J. 66 (2): 114-121.

14. Nie. W. B.;L. J.Fei. and X. Y.Ma. 2014. Applied Closed-end Furrow Irrigation Optimized Design Based on Field and Simulated Advance Data. J. Agr. Sci. Tech., 16: 395-408.

15. Pereira; L. S. and T. J. Trout. 1999. Irrigation Methods.CIGR Handbook of Agricultural Engineering.Published by ASAE; Michigan: 297-379.

16. Sanchez; C. A.;D.Zerihun and K.L. Farrell-Poe. 2009. Management Guidelines for Efficient Irrigation of Vegetables Using Closed-end Level Furrows. Agric. Water Manag.;96(1):43-52.

17. Schwankl; L. J.; N. S. Raghuwanshiand W. W. Wallender. 2000. Furrow irrigation performance under spatially varying conditions. Irrigation and Drainage Engineering J.; ASCE 126 (6): 355-361.

18. Strelkoff; T. 1991. SRFR - a model of surface irrigation - version 20. In: Ritter; W.F.; 1991: Irrigation and drainage; Proc. 1991 National Conf. Irrg. and Drainage Div. ASCE; Honolulu; Hawaii; July 22-26; 1991: 676-682.

19. Walker; W.R. and J. D. Busman. 1990. Real-time estimation of furrow infiltration; Irrigation and Drainage Eng. ASCE J.; 116(3): 299-318.

20. Walker; W.R. and G.V. Skogerboe. 1987. Surface irrigation: theory and practice. Prentice-Hall; Englewood Cliffs; USA.

21. Zerihun; D.; J. Feyen; and J. M. Reddy. 1997. Empirical Functions for Dependent Furrow Irrigation Variables. 1. Methodology and Equations. Irrig. Sci.; 17(3):111120.

22. Zerihun; D.; C. A. Sanchez and K. L. Farrell-Poe. 2001. Analysis and design of furrow irrigation systems. Irrigation and Drainage Engineering ASCE J.; 127(3): 161-169.

23. Zin EI-Abedin; T.K. and S.M. Ismail. 1999. Estimation and analysis of water advance in surface irrigation. Misr. J. Ag. Eng.; 16(4):720-744. 


\section{نمذجة تصميم نظام الري السطحي بالخطوط والتتبؤ بمتغيرات معدل التسرب تحت معدلات تصرف مختلفه

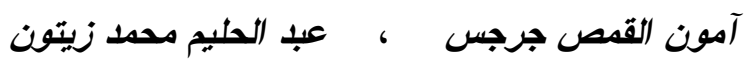

$$
\text { معهد بحوث الهندسة الزراعية - مركز البحوث الزراعية - الجيزة. }
$$

نظر الما تو اجهه بلادنا من قلة الموارد المائية ، لذاوجب التفكير في الطرق التي يمكن بها

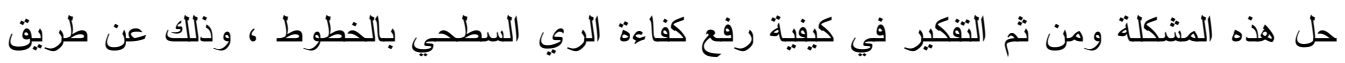
النقليل في كميات المياه المستخدمه مع زيادة كفاءة الري السطحي بالخطوط. في هذه الدراسة نم

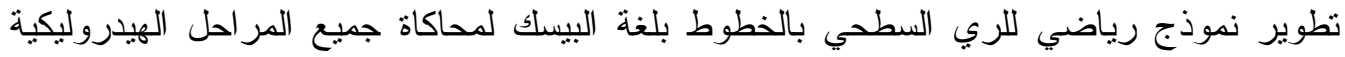

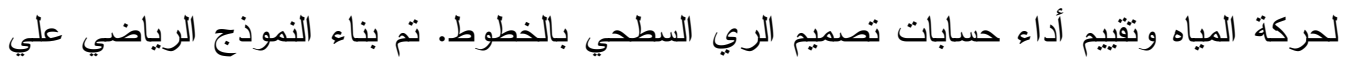
اساس نظرية التوازن الحجمي آخذين في الاعتبار المستهدف لعمق الماء المضاف وذلك لتقديم حلول وبدائل للتصميمات الحقلية والعمليات الإدارية باستخدام اجر اء نيوتن - رافسون (معدلات أضافة المياه

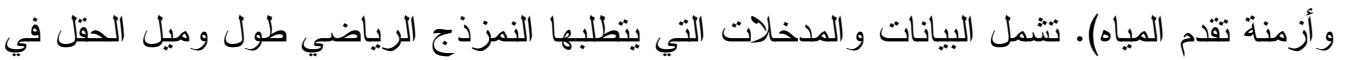

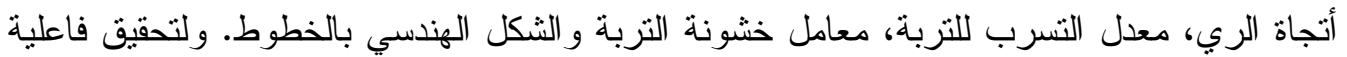
النموذج تمت مقارنة النتائج النظرية المتحصل عليها من النموذج الرياضي مع نتائج التجارب الحقلية

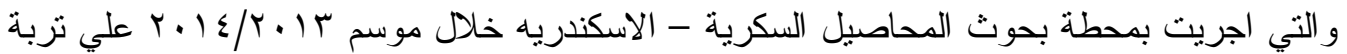
طينية. وقد شملت القياسات الحقلية كلا من شكل، طول، عرض الخطوط، الشكل الهندسي للخطوط، ميل الأرض في اتجاه الري بالإضافة الي أزمنة تقدم و انحسار و غلق المياه كذلك أعماق المياه داخل

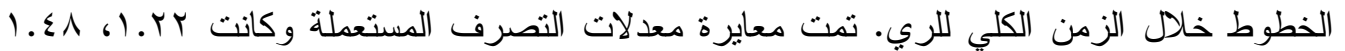

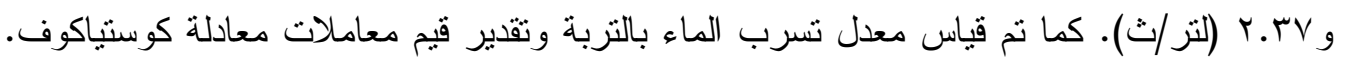

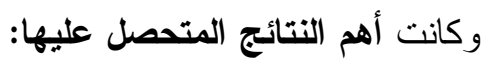

1- بمقارنة النتائج المتحصل عليها من النموذج الرياضي بنتائج التجارب الحقلية يتضح ان النموذج الرياضي استطاع وبكفاءة عالية التتبؤ بأزمنة تقدم وانحصار الريارئية المياه، أعماق وحجوم المياه

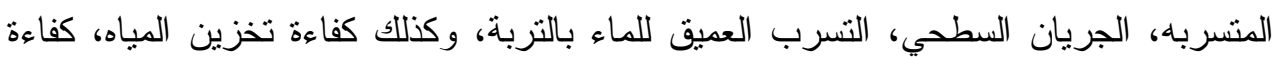

$$
\text { توزيع الماء بالتربة وكفاءة نطبيق المياه. }
$$

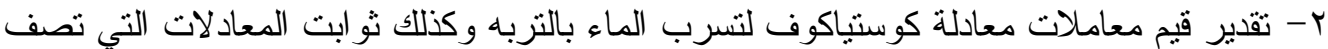

$$
\text { أعماق وحجوم المياه المتسربه داخل التربة. }
$$

r- أوضح إختبار حساسية النموذج الرياضي دقة عالية في تقدير القيم المقاسة و المحسوبة مقارنة بالنتائج الحقلية المتحصل عليها. ع - أوضحت النتائج امكانية استخدام النموذج الرياضي بصورة النئه جيدة وبدقة عالية في أجر اء التصميم

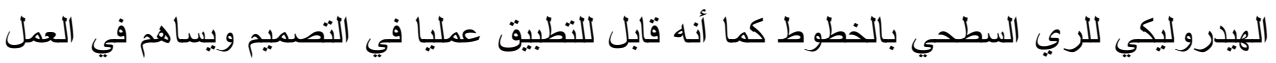
الأستشاري للحفاظ علي المياه و الأستخدام الأقتصادي و الأمثل للمياه. 